\title{
Effect of Sodium Hypochlorite Concentration during Pre-treatment on Isolation of Nanocrystalline Cellulose from Leucaena leucocephala (Lam.) Mature Pods
}

\author{
Aida Safina Aridi, ${ }^{\mathrm{a}, \mathrm{b}}$ Nyuk Ling Chin, ${ }^{\mathrm{a}}$ Nur Akmal Ishak, ${ }^{\mathrm{c}}$ Nor Nadiah Mohamad Yusof, ${ }^{\mathrm{d}}$ \\ Kazunori Kadota, ${ }^{e}$ Yanty Noorzianna Manaf, ${ }^{f}$ and Yus Aniza Yusof a,f,*
}

\begin{abstract}
Mature pods of Leucaena leucocephala (Lam.) de Wit were utilized as raw material for nanocrystalline cellulose (NCC) production. NCC's isolation begins with $L$. leucocephala fiber's alkaline treatment with sodium hydroxide, followed by bleaching treatment at three different percentages $(3 \%, 5 \%$, and $7 \%)$ of sodium hypochlorite. Acid hydrolysis was then conducted to obtain NCC, which was comprehensively characterized in terms of morphology, chemical functional groups, whiteness index, and crystallinity. Fourier-transform infrared spectroscopy (FTIR) and chemical composition results showed that alkali treatment $(\mathrm{NaOH})$ and bleaching $(3 \%, 5 \%$, and $7 \%$ of sodium hypochlorite, $\mathrm{NaClO}$ ) were effective in the removal of lignin and hemicellulose. The variation of sodium hypochlorite concentration affected physical and structural characteristics of the NCC produced, which exhibited a rod-shaped structure with diameters ranging from 17 to $49 \mathrm{~nm}$. These observations provide insight into the potential utilization of $L$. leucocephala as raw material for preparing nanocellulose, which may address problems of the underutilized mature pods.
\end{abstract}

Keywords: Leucaena leucocephala; Cellulose; Nanocrystalline cellulose; Agriculture waste; Biomaterial; Acid hydrolysis

Contact information: a: Department of Process and Food Engineering, Faculty of Engineering, Universiti Putra Malaysia, Serdang, 43400, Selangor, Malaysia; b: Faculty of Applied Science and Technology, Universiti Tun Hussein Onn Malaysia, Parit Raja, Batu Pahat, 86400, Johor, Malaysia; c: Biology Unit, Centre of Foundation Studies for Agricultural Science, Universiti Putra Malaysia, Serdang, 43400, Selangor, Malaysia; d: Polymer Engineering Technology, Universiti Kuala Lumpur, Malaysian Institute of Chemical and Bio-engineering Technology, Alor Gajah, 78000, Melaka, Malaysia; e: Department of Formulation Design and Pharmaceutical Technology, Osaka University of Pharmaceutical Sciences, 4-201 Nasahara, Takatsuki, Osaka 569-1094, Japan; f: Laboratory of Halal Science Research, Halal Products Research Institute, Universiti Putra Malaysia, Serdang, 43400, Selangor, Malaysia;

*Corresponding author: yus.aniza@upm.edu.my

\section{INTRODUCTION}

Awareness of environmental conservation has increased research activity in the search for new materials. A nanomaterial is defined as a material in which a single unit's size, in at least one dimension, is between $1 \mathrm{~nm}$ and $100 \mathrm{~nm}$. This unique nanomaterial is derived from a natural polymer, i.e., cellulose. Cellulose is the building block of cell walls in plants and acts as protection while providing for the plant cell walls. Plants are natural biocomposites and contain amorphous matrices made of hemicellulose, lignin, waxes, extractives, and trace elements (Halib et al. 2017; Phanthong et al. 2018).

Cellulose has obtained great attention from researchers and industry because it is an abundant polymer on earth. Moreover, cellulose is renewable, biodegradable, and 
nontoxic. This natural polymer has high mechanical strength and a high strength-to-weight ratio, allowing flexibility to counter substantial dimensional changes due to swelling and shrinking (Dufresne 2013). Cellulose has been used in many industries, such as the veterinary food, wood, paper, fiber, clothing, cosmetic, and pharmaceutical industries as an excipient (Shokri and Adibkia 2013; Ummartyotin and Manuspiya 2015). Statistic data from Statista Research Department (2016) forecasted figures for 2018 to 2025, by application. In 2025, it is forecasted that the U.S. market value of cellulose fiber used for hygiene applications will amount to approximately 700 million U.S. dollars.

The benefits of cellulose can be further extended when cellulose chains are bundled together, generating highly ordered regions that can be subsequently isolated to produce cellulose nanomaterials or nanocellulose. Nanocellulose can be categorized into three major classes: nanocrystalline cellulose (NCC), nanofibrillated cellulose (NFC), and bacterial nanocrystalline cellulose (BNC) (Phanthong et al. 2018). These forms of nanocellulose have similarities in chemical composition but differ in morphology, particle size, crystallinity, and isolation methods (Lavoine et al. 2012). The market value of nanocellulose was estimated to amount to 297 million U.S. dollars worldwide in 2020. It is expected to increase considerably by 2025 , to a forecasted value of 783 million U.S. dollars (Garside 2021). This data shows that the nanocellulose industry is a great field to be explored and produced.

Malaysia is a tropical country that has abundant natural resources from its agricultural sector. For many years, Leucaena leucocephala (Lam.) de Wit, also known as "petai belalang" has been a source of fiber and protein. It is a fast-growing tropical legume tree native to Mexico and Central America. It is a thornless, evergreen, branched shrub or small tree up to $8 \mathrm{~m}$ high with deep roots. The trunk is greyish brown, and the leaves are alternate and bipinnate, up to $25 \mathrm{~cm}$ long, with 12 to 18 pairs of small, shortly stalked, linear or linear-oblong, acute, dull greyish green, glabrous leaflets, $10 \mathrm{~mm}$ to $15 \mathrm{~mm}$ by 3 $\mathrm{mm}$ to $4 \mathrm{~mm}$ wide, with minute stipules (Lim 2012). This plant's fruit is a broadly linear (strap-shaped), thin, flat pod, $12 \mathrm{~cm}$ to $14 \mathrm{~cm}$ long by $1.5 \mathrm{~cm}$ wide. It is light green when immature and then turns brown and dry when ripe, containing 15 to 30 seeds. Seeds are ovate-oblong, flat, $6 \mathrm{~mm}$ to $10 \mathrm{~mm}$ long, and green when immature, turning dark brown. The plant has many economic advantages, including high biomass production. In the 1970s and 1980s, these species were known as the "miracle trees" (Verma 2016) because of their numerous applications, mostly in the livestock industry (Sethi and Kulkarni 1994; Aminah and Wong 2004). The species is also used for pulp and paper production due to its low lignin content (Pandey and Kumar 2013). In India, a Leucaena leucocephala farm forestry plantation program initiated by JK Paper Ltd had been developed because of its potential to be used as a new material for the paper industry (Khanna et al. 2019).

In Malaysia, this plant had been used as the source of raw material for the wood composite industry as an alternative to the wood residue and rubberwood. Mohd et al. (2020) reported that this tree showed a positive growth rate relative to the tree height, which means that as the tree's age is increased, its height will also increase. It was found that $L$. leucocephala can be a suitable alternative for particleboard manufacturing. Besides that, cellulose was successfully isolated from this plant's seeds (Husin and Ab 2019). The diameter of cellulose and microcrystalline cellulose from the seeds was approximately 5 $\mu \mathrm{m}$ to $10 \mu \mathrm{m}$, similar to or lower than those of other plant fibers reported by others (Jahan et al. 2011; Nuruddin et al. 2011). The isolation and purification of cellulose involves two steps, namely pulping and bleaching (Kamel et al. 2020). Chemical pulping aims to eliminate hemicellulose, and lignin. Usually, this process uses pulping agents such as alkali 
or organic solvent to remove non-cellulosic components. The step that comes after pulping is bleaching, which is an integrated step in the pulping process. The example of bleaching agents used in this process are sodium hypochlorite, sodium chlorite, and hydrogen peroxide. Although there have been many studies investigating cellulose isolation from plants, the effects of concentration variation during pre-treatment on the structure and physical properties of the obtained NCC have not been studied.

Thus, this study aimed to isolate NCC from L. leucocephala pods and investigate the effects of concentration variation during bleaching treatment on the properties and morphology of the obtained NCC. The L. leucocephala mature pod's utilization is important for increasing the mature pod value because of its potentially high cellulose content. The novelty of this study is to investigate the use of L. leucocephala mature pod as a new material for isolation of nanocrystalline cellulose, intending to provide another application of this plant other than use in animal feed (leaves) (Masafu 2006), biodiesel production (seeds) (Hakimi et al. 2017), and the paper industry (wood) (Rahman et al. 2014). Moreover, to date, no study has been done to investigate how different percentages of sodium hypochlorite during the bleaching process can affect the characteristics of NCC produced. The influences of different concentrations of $\mathrm{NaClO}$ during pre-treatment on the yield, color, functional groups, crystallinity, and morphology of L. leucocephala fibers were investigated. The proximate and amino acid analysis of mature pod was provided, as most of the previous research data was only focused on the leaves, seed, and tree. In this work, the NCC was produced from L. leucocephala mature pods, which are a readily available and inexpensive material. Pre-treatment was performed to remove non-cellulosic materials, such as hemicellulose and lignin, making the cellulose more accessible to acid during hydrolysis.

\section{EXPERIMENTAL}

\section{Materials}

Leucaena leucocephala (Lam.) de Wit. (voucher No. MFI 0079/19) mature pods as lignocellulosic materials were collected from trees available at the Faculty of Engineering, Universiti Putra Malaysia. The confirmation of plant species was done at Biodiversity Unit, Institute of Bioscience, Universiti Putra Malaysia. The plant was identified as Leucaena leucocephala (Lam.) de Wit, under the family name of Fabaceae. It is also known as "Petai belalang" for the local name. Acetic acid $\left(\mathrm{CH}_{3} \mathrm{COOH}\right)$, sodium hydroxide $(\mathrm{NaOH})$, sodium hypochlorite $(\mathrm{NaClO})$, sodium chlorite $\left(\mathrm{NaClO}_{2}\right)$, acetic acid $\left(\mathrm{CH}_{3} \mathrm{COOH}\right)$, and sulphuric acid $\left(\mathrm{H}_{2} \mathrm{SO}_{4}\right)$ was purchased from the company Evergreen Engineering \& Resources (Selangor, Malaysia). All the chemicals used in this study were analytical grade and applied without further purification.

\section{Proximate and Amino Acid Composition of L. leucocephala Mature Pod}

The percentage of crude protein, crude fat, ash, and moisture content of $L$. leucocephala mature pods were analyzed using AOAC (2005). The nitrogen was determined by the micro-Kjeldahl method described by Pearson (1976); the percentage of nitrogen was converted to crude protein by a multiplication method (Aborisade et al. 2017). All determinations were performed in triplicates. Next, the amino acid analysis was performed using High-Performance Liquid Chromatography (HPLC) with a Fluorescence detector at Halal Products Research Institute, Universiti Putra Malaysia. 


\section{Alkali Treatment of Leucaena leucocephala Pods}

The L. leucocephala pods collected were brown, and the lengths of the pods ranged from 14 to $18 \mathrm{~cm}$. All collected pods were cleaned under running tap water and dried overnight in an oven (Memmert Universal Oven, Memmert GmbH + Co. K.G., Schwabach, Germany) at $100{ }^{\circ} \mathrm{C}$. The dried pods were ground using a milling machine (Laboratory Mill 120, Perten Instruments, Hägersten, Sweden) and then sieved through a vibrating sieve shaker machine (AS 200 Control, Retsch Gmbh, Haan, Germany) to obtain a powder size of $0.25 \mathrm{~mm}$ and below. The pre-treatment of the L. leucocephala pods was performed using the method described by (Zheng et al. 2019). This treatment aimed to eliminate hemicellulose from the L. leucocephala pods to obtain purified cellulose. The fiber was mixed with $2 \mathrm{wt} \%$ of $\mathrm{NaOH}$ solution in a solid-to-liquid ratio of $1 \mathrm{~g} / 10 \mathrm{~mL}$, shaken at 50 $\mathrm{rpm}$, and heated at $100{ }^{\circ} \mathrm{C}$ in a shaking water bath machine (BS-06/11/21/31, Daejeon, Korea) for 4 hours. This alkali treatment was repeated four times until no more discoloration occurred, and the product obtained after the treatment was referred to as alkali L. leucocephala (A-LL). The fiber was then washed with distilled water to a $\mathrm{pH}$ of 7 and proceeded to the second pre-treatment.

\section{Bleaching Treatment}

The bleaching treatment was performed using three different percentages $(3 \%, 5 \%$, and $7 \%$ ) of $\mathrm{NaClO}$. Sodium hypochlorite was chosen as the bleaching agent. Aridi et al. (2020) reported that $5 \%$ of sodium hypochlorite was the best bleaching agent in removing hemicellulose and lignin from the fiber. Besides that, a study by Aurelia et al. (2019) also investigated the bleaching process of Jack Bean skin by using 0,3 , and $6 \%$ of $\mathrm{NaClO}$. They found out that $3 \%$ of $\mathrm{NaClO}$ gives the best results, with a high cellulose content, light color, and FTIR peaks similar to commercial cellulose. Thus, for this study, 3\%, 5\%, and $7 \%$ of $\mathrm{NaClO}$ were chosen to investigate the effect of using different percentages of $\mathrm{NaClO}$ to characterize NCC obtained from the L. leucocephala mature pod. The solid-to-liquid ratio used was $1 \mathrm{~g}$ of powder to $50 \mathrm{~mL}$ of bleaching agent solution. The solution was then heated at $80{ }^{\circ} \mathrm{C}$ and shaken at $100 \mathrm{rpm}$ for 2 hours using a shaking water bath. The specimen was bleached twice to obtain a white powder. The bleached powder was then thoroughly washed with distilled water to a $\mathrm{pH}$ of 7 , and it was referred to as bleached L. leucocephala (B-LL). The cellulose samples obtained were labeled as B-LL3, B-LL5, and B-LL7.

\section{Isolation of NCC}

Nanocrystalline cellulose from the L. leucocephala pods was obtained by sulfuric acid $\left(\mathrm{H}_{2} \mathrm{SO}_{4}\right)$ hydrolysis according to the method of Song et al. (2019). One gram of pretreated L. leucocephala pod powders was slowly added into $30 \mathrm{~mL}$ of $\mathrm{H}_{2} \mathrm{SO}_{4}$ solution (63 wt.\%) with vigorous stirring at room temperature $\left(25^{\circ} \mathrm{C}\right)$ for $1 \mathrm{~h}$. Then, the hydrolysis solution was quenched by adding ice water $(300 \mathrm{~mL})$ into the mixture. The resultant mixture was then centrifuged at $9000 \mathrm{rpm}$ for $15 \mathrm{~min}$ three times to obtain NCC. The obtained NCC was dialyzed against distilled water for 3 days and sonicated at $50 \%$ amplitude using a sonicator (Qsonica Sonicator Q500, Thermo Fisher Scientific, Waltham, MA, USA) for $15 \mathrm{~min}$. The obtained NCC was then freeze-dried using a freeze dryer (ScanVac CoolSafe, LaboGene, Allerød, Denmark) at $-110^{\circ} \mathrm{C}$ with a vacuum pump (two stages with $2 \mathrm{~m}^{3} / \mathrm{h}$ to $5 \mathrm{~m}^{3} / \mathrm{h}$ capacity), and the freeze-drying process was performed for 24 $\mathrm{h}$ to obtain a fine powder for further analysis. The nanocrystalline cellulose samples obtained were labeled as N-LL3, N-LL5, and N-LL7. 


\section{Determination of Chemical Compositions}

Leucaena leucocephala fibers' chemical composition was determined at different stages such as raw fibers, bleached fibers, and alkali-treated fibers. According to a standard method of the Technical Association of the Pulp and Paper Industry (TAPPI T13m), the lignin content was measured. One g of sample was placed in a small beaker, and $72 \%$ of sulfuric acid $(15 \mathrm{~mL})$ was added slowly with stirring. The mixture was allowed to stand for $2 \mathrm{~h}$ in a water bath at $20{ }^{\circ} \mathrm{C}$, with frequent stirring. The mixture was washed into a 1-liter beaker, and $500 \mathrm{~mL}$ of water was added for dilution to a sulfuric acid concentration of $3 \%$. The solution is then boiled for $4 \mathrm{~h}$ with the periodic addition of hot water to maintain the volume. The insoluble lignin was allowed to settle, and then the mixture was filtered into a crucible, which has been previously dried at $105^{\circ} \mathrm{C}$. The crucible and contents were dried in an oven at $105^{\circ} \mathrm{C}$ for $2 \mathrm{~h}$, cooled in a desiccator, and weighed. The drying and weighing were repeated until the weight was constant (Browning 1967; Dos Santosa et al. 2013). The lignin quantity was calculated using Eq. (1)

$$
\operatorname{Lignin}(\%)=\left(M_{1} / M\right) \times 100
$$

where $M_{1}$ is the obtained lignin mass and $M$ is the initial sample mass

The holocellulose content of the samples was determined according to the method proposed by (Abdul Rahman et al. 2017). The fibers were soaked in a solution of $5 \mathrm{wt} \%$ acidified aqueous sodium chlorite $\left(\mathrm{NaClO}_{2}\right)$ at $70{ }^{\circ} \mathrm{C}$ for $1 \mathrm{~h}$ with a weight ratio of 1:20 fiber-to- $\mathrm{NaClO}_{2}$ solution. Before that, the $\mathrm{NaClO}_{2}$ solution was acidified with sulfuric acid $\left(\mathrm{H}_{2} \mathrm{SO}_{4}\right)$ solution until the $\mathrm{pH}$ reached 4 . The sample's residue was then filtered from the solution, washed using distilled water and dried in an oven at $60^{\circ} \mathrm{C}$. The residue was finally dried and weighed. The holocellulose content was calculated using Eq. (2)

$$
\text { Holocellulose }(\%)=\left(M_{2} / M\right) \times 100
$$

where $M_{2}$ is the obtained residue mass and $M$ is the initial sample mass

Meanwhile, the composition of cellulose was evaluated by soaking the holocellulose for $24 \mathrm{~h}$ with $6 \mathrm{wt} \%$ of potassium hydroxide solution at room temperature. After that, the sample was filtered, washed with distilled water, and oven-dried at $60{ }^{\circ} \mathrm{C}$ until a constant weight was obtained. The hemicellulose content of the fibers is the difference between the values of holocellulose and cellulose, Eq. 3,

$$
\text { Cellulose }(\%)=\left(M_{3} / M\right) \times 100
$$

where $M_{3}$ is the obtained white powder mass and $M$ is the initial sample mass.

\section{Whiteness Index Analysis}

All samples' reflective surface colors were measured using a Benchtop Spectrophotometer, a color measurement system (CM-3600A, Konica Minolta, Tokyo, Japan). Reflectance specular excluded (RSEX) mode was used, and the area view was 0.190 inches. The values of $L^{*}, a^{*}$, and $b^{*}$ were recorded, and each sample was individually measured in triplicate. The whiteness index (W.I., \%) was calculated using Eq. 4 (Yen et al. 2009):

$$
W I(\%)=100-\left[\left(100-L^{*}\right)^{2}+\left(a^{*}\right)^{2}+\left(b^{*}\right)^{2}\right]^{1 / 2}
$$




\section{Morphology Analysis}

Field emission scanning electron microscopy (FESEM) images were made using an FEI Nova NanoSEM 230 scanning electron microscope (Field Electron and Ion Company, FEI, Oregon, USA) with an accelerating voltage of $3 \mathrm{kV}$ to observe the microstructural and nano structural surfaces of the longitudinal cross-sections of dried untreated L. leucocephala fibers, as well as the fibers after different stages of treatment and the NCC obtained. Also, the NCC's nano structural images were made using a transmission electron microscope (Philips Tecnai 20, Amsterdam, Netherlands) with an acceleration voltage of $200 \mathrm{kV}$ and a standard inclined sample holder. First, a suspension of NCCs with different bleaching treatments was dispersed by ultrasonication of particles in distilled water for $10 \mathrm{~min}$. After that, one drop of a diluted suspension of NCCs was placed on a carbon-coated copper grid and allowed to dry at room temperature $\left(25{ }^{\circ} \mathrm{C}\right)$. The transmission electron micrographs of the nanostructures were enhanced to improve the resolutions.

\section{Functional Group Analysis Using Fourier-transform Infrared (FTIR) Spectroscopy}

The FTIR spectra of all samples were analyzed using an FTIR spectrometer (Nicolet ${ }^{\mathrm{TM}}$ iS20, Thermo Fisher Scientific, Waltham, MA, USA) equipped with an attenuated total reflectance (ATR) element. All the samples' powders were pressed into a pellet before FTIR analysis, in which potassium bromide $(\mathrm{KBr})$ was used as the diluent. A spatula full of $\mathrm{KBr}$ was added into an agate mortar and ground to a fine powder until no crystallites were observed. Then, a small amount of an NCC sample was mixed with the $\mathrm{KBr}$ powder. Subsequently, the mixture was ground for $3 \mathrm{~min}$ to $5 \mathrm{~min}$. Next, the powder was added into a 7-mm collar and pressed with a small hydraulic press to produce a pellet. A good $\mathrm{KBr}$ pellet is thin and transparent. The pellet was then put onto the sample holder to begin scanning. The FTIR spectra were then collected in the mid-infrared region (400 to $4000 \mathrm{~cm}^{-1}$ ) using 32 scans, and the resolution was $4 \mathrm{~cm}^{-1}$. The OMNIC software (version 8.0, Thermo Fisher Scientific, Waltham, MA, USA) was used for data analysis.

\section{Crystal Analysis Using X-ray Diffraction (XRD)}

The XRD analysis of all samples was conducted at the Centre for Research and Instrumentation Management, Universiti Kebangsaan Malaysia, Bangi, Malaysia. A Bruker D8 Advance (Billerica, MA, USA) equipped with $\mathrm{CuK} \alpha$ radiation $(\lambda=0.1541 \mathrm{~nm})$ was used to study the XRD patterns in the $2 \theta$ range of $5^{\circ}$ to $80^{\circ}$ of the untreated fiber, alkali-treated fiber, and NCC. The crystallinity index $(\mathrm{CrI}, \%)$ was calculated according to the method reported by Zheng et al. (2019) (Eq. 5),

$$
\operatorname{CrI}(\%)=\left(I_{200}-I_{\mathrm{am}}\right) / I_{200} \times 100
$$

where $I_{002}$ is the maximum intensity of the diffraction at the 200 peaks $\left(2 \theta=22.06^{\circ}\right)$, and $I_{\mathrm{am}}$ is the intensity of the diffraction at $2 \theta=18^{\circ}$.

\section{Density and Moisture Content}

The density was measured using gas intrusion under a helium gas flow with an AccuPyc 1340 pycnometer. The samples were oven dried at $105^{\circ} \mathrm{C}$ overnight to remove moisture content within the fibers. Then, they were placed inside the desiccator to remove traces of water from almost-dry sample before place inside the pycnometer. Five measurements were conducted at $27^{\circ} \mathrm{C}$, and the average was calculated. For moisture 
content, three samples were prepared and heated in an oven for 24 hours at $10{ }^{\circ} \mathrm{C}$. The weights of samples before, $M_{\mathrm{i}}$, and after $M_{\mathrm{f}}$ the heating were measured in order to calculate the moisture content. Then, the moisture content was determined using Eq. (6).

Moisture content $(\%)=\left(M_{\mathrm{i}}-M_{\mathrm{f}}\right) / M_{\mathrm{i}} \times 100$

\section{RESULTS AND DISCUSSION}

\section{Proximate and Amino Acid Analysis of $L$. leucocephala Mature Pods}

Leucaena leucocephala, also known as petai belalang in Malaysia, is one of the fast-growing leguminous trees (Sethi and Kulkarni 1995). In India, it is an important plant that is encouraged to be grown under social forestry schemes, as it provides useful timber and paper industry (Khanna et al. 2019). In this study, the proximate and amino acid composition of L. leucocephala mature pods were investigated, and its suitability for the raw material for isolation of nanocrystalline cellulose was determined. From Table 1, the carbohydrate showed the highest content with $78.08 \mathrm{~g}$, and fat showed the lowest composition with only $0.46 \mathrm{~g}$. The other components, which included moisture, ash, and protein, were $8.79,5.23$, and $7.45 \mathrm{~g}$. The protein content of Leucaena seeds was higher than its pods, as reported by Sethi and Kulkarni (1995), which explains why most of the applications of L. leucocephala tress is focused on the leaves, seeds, and young pod for animal feed.

Table 1. Proximate Data of Mature Pod Leucaena leuocephala

\begin{tabular}{|c|c|}
\hline Composition & Unit $(\mathrm{g} / 100 \mathrm{~g})$ \\
\hline Moisture & 8.8 \\
\hline Ash & 5.2 \\
\hline Total protein & 7.5 \\
\hline Total fat & 0.5 \\
\hline Carbohydrate & 78.1 \\
\hline Energy & 346 \\
\hline
\end{tabular}

Besides that, the amino acid composition of L. leucocephala mature pods is presented in Table 2. The amino acid is important in plants, as they play a major role as a constituent of proteins. From Table 2, aspartic acid showed the highest percentage, which was $25.36 \%$, and valine showed the lowest, with only 0.09\%. Sethi and Kulkarni (1995) differently reported the data obtained from the analysis of L. leucocephala seeds. It was reported that the seeds are fairly rich in essential amino acids such as isoleucine, leucine, phenylalanine, and histidine.

\section{Yield Percentage and Whiteness Index}

The alkali treatment and bleaching of L. leucocephala fibers caused partial defibrillation and fiber bundles. The cementing components, such as hemicellulose and lignin, were removed via the alkali and bleaching treatments. These two steps were critical for more efficient NCC hydrolysis. Each of the microfibril bundles was composed of a NCC bundle connected with the microfibril by the amorphous region. Amorphous regions were eliminated by acid hydrolysis to obtain a high yield of NCC, resulting in diameter 
reduction and separation of fibers, from micron-sized fibers to individual nanofibers (Samir et al. 2005; Ilyas et al. 2018). Generally, these NCCs are in the ranges of $100 \mathrm{~nm}$ to 250 $\mathrm{nm}$ in length and $5 \mathrm{~nm}$ to $80 \mathrm{~nm}$ in diameter, and most cellulosic materials become more or less individualized through sonication (Bondeson et al. 2006).

Table 2. Amino Acid Composition of Mature Pod L. leuocephala

\begin{tabular}{|c|c|c|}
\hline Amino acid compound & Compound weight $(\mathrm{ng})$ & Compound \% $(\mathrm{w} / \mathrm{w})$ \\
\hline Hydroxyproline & 2.4 & 1.6 \\
\hline Aspartic acid & 37.8 & 25.4 \\
\hline Serine & 6.3 & 4.2 \\
\hline Glutamic acid & 18.1 & 12.1 \\
\hline Glycine & 6.2 & 4.2 \\
\hline Histidine & 3.8 & 2.6 \\
\hline Arginine & 9.0 & 6.1 \\
\hline Threonine & 7.3 & 4.9 \\
\hline Alanine & 8.2 & 5.5 \\
\hline Proline & 8.9 & 6.0 \\
\hline Cysteine & 3.3 & 2.2 \\
\hline Tyrosine & 2.7 & 1.8 \\
\hline Valine & 0.1 & 0.1 \\
\hline Methionine & 6.6 & 4.4 \\
\hline Lysine & 10.7 & 7.2 \\
\hline Isoleucine & 2.0 & 3.4 \\
\hline Leucine & 8.2 & 5.5 \\
\hline Phenylalanine & 4.4 & 2.9 \\
\hline
\end{tabular}

The yield of NCC isolated from the L. leucocephala (Lam.) de Wit fibers increased to $79.1 \%$ for $5 \%$ of $\mathrm{NCC}$, as the percentage of $\mathrm{NaClO}$ was increased (Table 3 ). However, the yield of NCC started to decrease when $7 \%$ of $\mathrm{NaClO}$ was used. External factors such as loss during the washing treatment may also play a role in the cellulose weight loss. Furthermore, cellulose yield decreased significantly with the increasing percentage of $\mathrm{NaClO}$ due to the rupture of the glycosidic bond in the cellulose, also known as cellulose degradation. $\mathrm{NaClO}$ can oxidize cellulose specifically in its amorphous zone (Aurelia et al. 2019; Wertz et al. 2010). The oxidation starts with converting a glucose unit to its unstable derivative, followed by the opening of its ring and the rupture of its linkage. This reaction leads to a decrease in the cellulose's molecular weight and an increase in its solubility. Next, the whiteness indices of all samples are also presented in Table 3. The whiteness index increased after the alkali and bleaching treatments were performed on the fibers. This result shows that the bleaching treatment with $\mathrm{NaClO}$ successfully removed the lignin, increasing the whiteness and leaving the cellulose. High concentrations of $\mathrm{NaClO}$ during the bleaching treatment led to a lighter color in the cellulose produced. Lignin is a polymer responsible for the brownish color of cellulosic material (Aurelia et al. 2019). However, at $7 \%$ of NCC, the whiteness index started to decrease, to $61.3 \%$. This finding was similar to the work of Aurelia et al. (2019). They found that cellulose from jack bean skin started to become slightly brownish after the percentage of $\mathrm{NaClO}$ increased to $6 \%$. 
Table 3. Yield Percentages and Whiteness Indices of NCC at Different Percentages of $\mathrm{NaClO}$

\begin{tabular}{|c|c|c|}
\hline Sample & Yield (\%) & Whiteness Index (\%) \\
\hline Untreated & - & $51.5 \pm 1.1$ \\
\hline Alkali treated & $22.4 \pm 0.43$ & $64.3 \pm 0.9$ \\
\hline $3 \% \mathrm{NaClO}$ & $56.2 \pm 1.0$ & $68.8 \pm 0.4$ \\
\hline $5 \% \mathrm{NaClO}$ & $79.1 \pm 0.6$ & $78.5 \pm 0.1$ \\
\hline $7 \% \mathrm{NaClO}$ & $55.4 \pm 0.7$ & $61.3 \pm 0.5$ \\
\hline
\end{tabular}

\section{Chemical Composition of Leucaena leucocephala Fiber}

The chemical composition of L. leucocephala fiber at each stage of chemical treatments is shown in Table 4. The untreated mature L. leucocephala pod consisted of $36.6 \%$ cellulose, $21.7 \%$ hemicellulose, and $29.5 \%$ lignin. In alkali treatment with sodium hydroxide $(\mathrm{NaOH})$, it was effective in eliminating the surface impurities, hemicellulose, and lignin from the mature pod, as the amount of hemicellulose was decreased from 21.7 to $15.7 \%$. In comparison, the lignin content was reduced to from 29.5 to $11.0 \%$.

The effect of different percentages of sodium hypochlorite $(\mathrm{NaClO})$ during the bleaching process on the effectiveness of removing hemicellulose and lignin contents in the mature pod was also investigated. From Table 4, cellulose treated with 7\% $\mathrm{NaClO}$ showed the highest percentage, which is $89.5 \%$, compared to cellulose treated with $3 \%$ $\mathrm{NaClO}$, which only $69.5 \%$. This result showed that the treatments were efficient in removing most hemicellulose and lignin, thus resulting in high cellulose content.

Table 4. Chemical Composition of Raw Leucaena leucocephala Mature Pods and Treated Nature Pods

\begin{tabular}{|c|c|c|c|c|}
\hline Material & Holocellulose (\%) & Cellulose (\%) & Hemicellulose (\%) & Lignin (\%) \\
\hline Untreated & 58.3 & 36.6 & 21.7 & 29.5 \\
\hline Alkali treated & 74.1 & 58.4 & 15.7 & 11.0 \\
\hline $3 \% \mathrm{NaClO}$ & 79.5 & 69.5 & 10.0 & 5.4 \\
\hline $5 \% \mathrm{NaClO}$ & 85.6 & 82.2 & 3.4 & 2.4 \\
\hline $7 \% \mathrm{NaClO}$ & 90.9 & 89.5 & 1.4 & 0.9 \\
\hline
\end{tabular}

\section{Morphology Observation}

The alkali and bleaching treatments altered the chemical compositions of the treated fibers and affect the fiber surface structure. Figure 1 shows the untreated and alkali-treated L. leucocephala (Lam.) de Wit fibers' morphologies. The fibers' color changed from dark brown (Fig. 1a) to light brown (Fig. 1b) after the alkali treatment. The FESEM analysis of the NCC isolated from the L. leucocephala fibers is presented in Fig. 2. At 500x magnification (Fig. 1c), it showed that the untreated L. leucocephala fiber had a smooth surface. It had a long rod shape and was bonded together by cementing components, hemicellulose and lignin. However, the surface of the alkali-treated L. leucocephala fiber became rough, with an irregular porous structure (Fig. 1d). This result was because hemicellulose was hydrolyzed and became water-soluble, helping in the fibrils' defibrillation, as shown in the micrograph in Fig. 1d. A study by Husin and Ab (2019) showed a similar alkali-treated structure. This result was because treatment with sodium hydroxide eliminates the fiber's hemicellulose group, thus resulting in a rough structure and leaving behind the cellulose and lignin. Similar morphology was observed for 
Calotropis procera fiber after the pre-treatment. It became rough, and many wrinkles were formed, as reported by Song et al. (2019), and NCC isolated from sugar palm fibers were rough with pore-like structure (Ilyas et al. 2018).

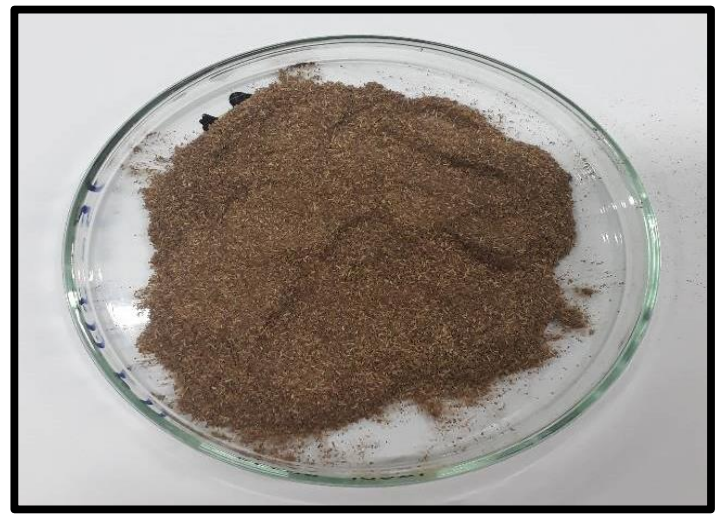

(a)
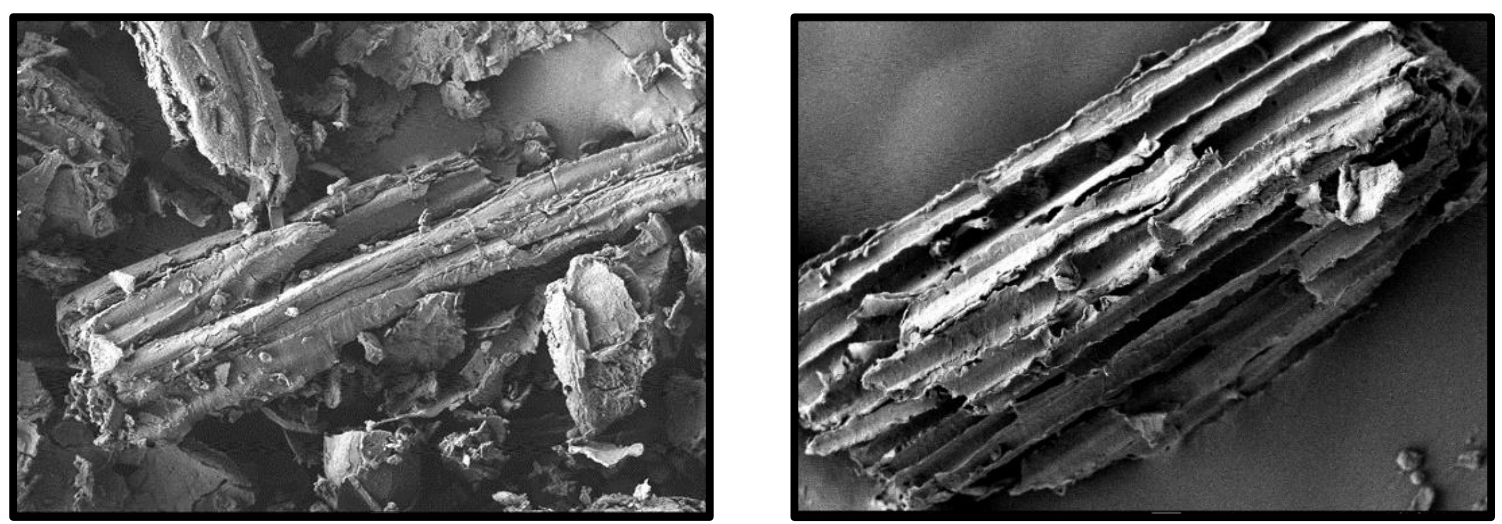

(c)

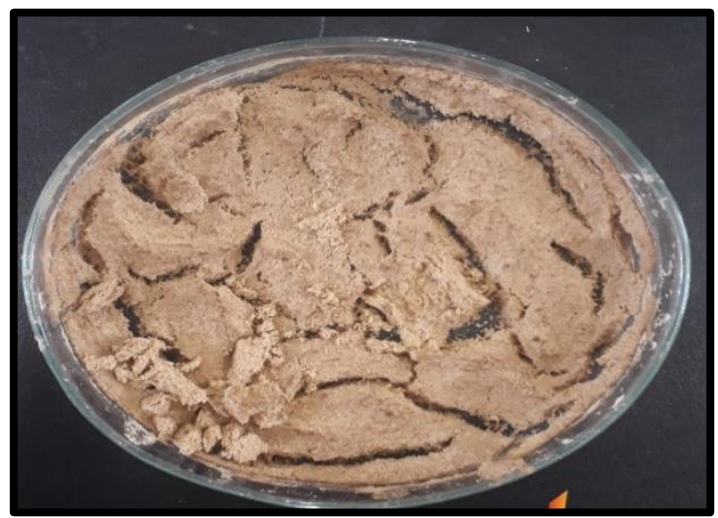

(b) (d)

Fig. 1. (a) Untreated and (b) alkali-treated mature Leucaena leucocephala (Lam.) de Wit pod fibers; FESEM analysis of (c) untreated and (d) alkali-treated mature L. leucocephala pod fiber, at $500 \times$ magnification

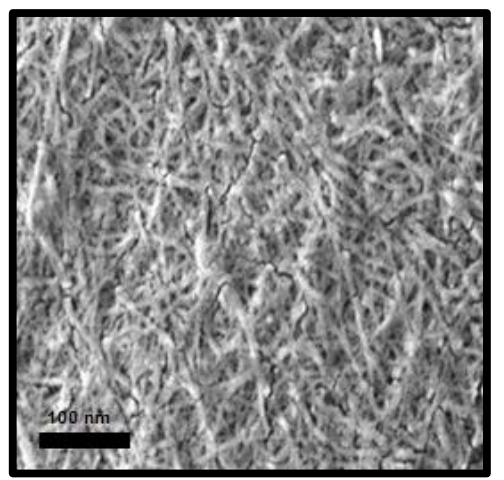

(a)

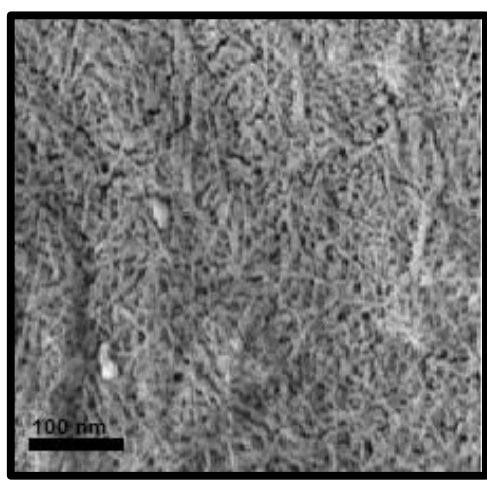

(b)

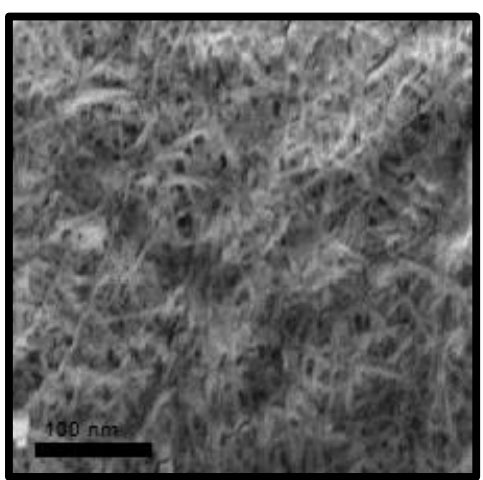

(c)

Fig. 2. FESEM images of NCC with (a) $3 \%$, (b) $5 \%$, and (c) $7 \%$ of $\mathrm{NaClO}$ treatment, at $50,000 \times$ magnification 
Moreover, the NCC isolated from the L. leucocephala became white after the bleaching treatment with $\mathrm{NaClO}$ (Fig. 3). With 3\% bleach, it showed a less white color, which increased as the percentage of $\mathrm{NaClO}$ increased. The whiteness index of the NCC increased as the percentage of $\mathrm{NaClO}$ increased during bleaching. However, the whiteness index of $\mathrm{NCC}$ was decreased as $7 \%$ of $\mathrm{NaClO}$ used during bleaching. This result is supported by a previous study investigating the effect of $\mathrm{NaClO}$ concentration on the cellulose produced from jack been skin (Aurelia et al. 2019). They found that a combination of $10 \%$ sodium hydroxide and $3 \%$ of $\mathrm{NaClO}$ could produce the best cellulose quality.

The FESEM images of the NCC isolated from the L. leucocephala fibers are shown in Fig. 2, with a magnification of 50,000×. With $3 \%$ of $\mathrm{NaClO}$, the $\mathrm{NCC}$ had a rod-shaped structure (Fig. 2a). Refinement of the fibrillar structure is associated with a further reduction in its diameter and intermittent breakdown of the fibrillar structure, as shown in the NCC morphology. The NCC started to become smaller and to agglomerate as the percentage of $\mathrm{NaClO}$ was increased. At $7 \%$ of $\mathrm{NaClO}$ (Fig. 2c), the shape of the NCC produced were started to disappear. At $7 \%$ of $\mathrm{NaClO}$, the $\mathrm{NCC}$ looked like a paste, rather than being rod or needle-shaped. Also, 3\% and 5\% NCC had a similar shape with the NCC isolated from water hyacinth fiber (Figs. 2a and b). This result occurs due to depolymerization (Asrofi et al. 2018).

Figure 3 presents images of the bleached cellulose and NCC powder. The NCCs were whiter than the bleached cellulose. Besides, transmission electron microscopy (TEM) images of individual NCC particles are shown in Fig. 4.

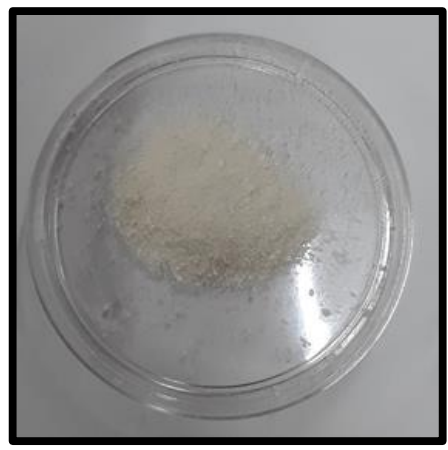

(a)

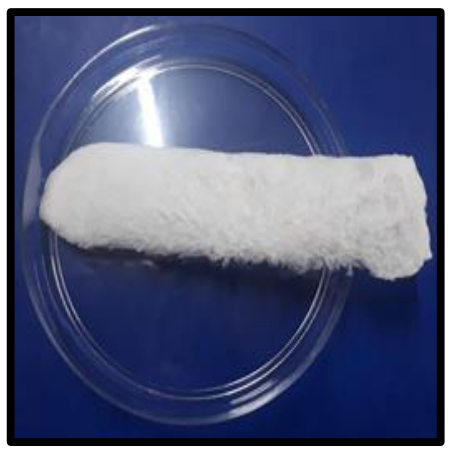

(d)

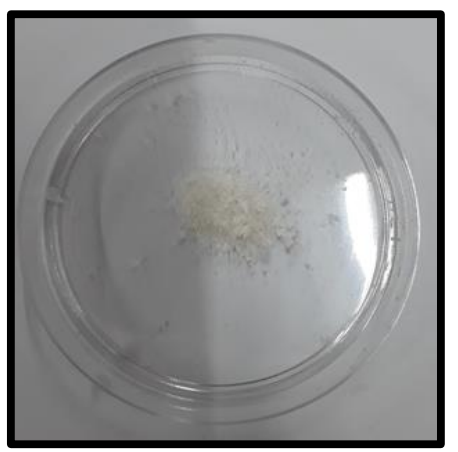

(b)

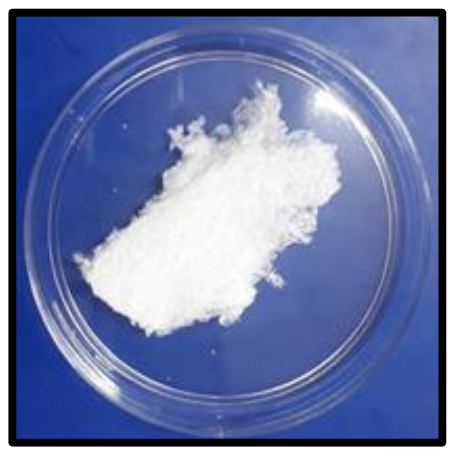

(e)
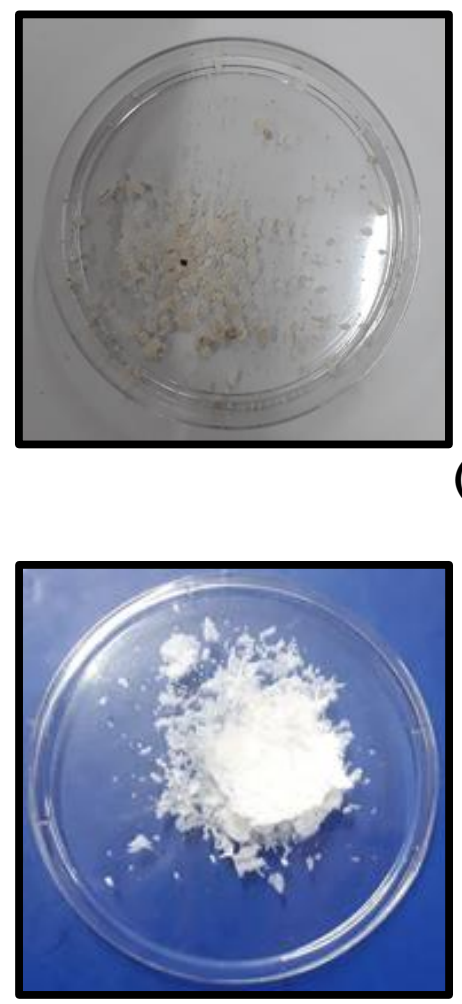

(c)

\section{(f)}

Fig. 3. Powders of bleached cellulose treated with (a) $3 \%$, (b) $5 \%$, and (c) $7 \%$ of $\mathrm{NaClO}$; NCC treated with (d) $3 \%$, (e) $5 \%$, and (f) $7 \%$ of $\mathrm{NaClO}$ 

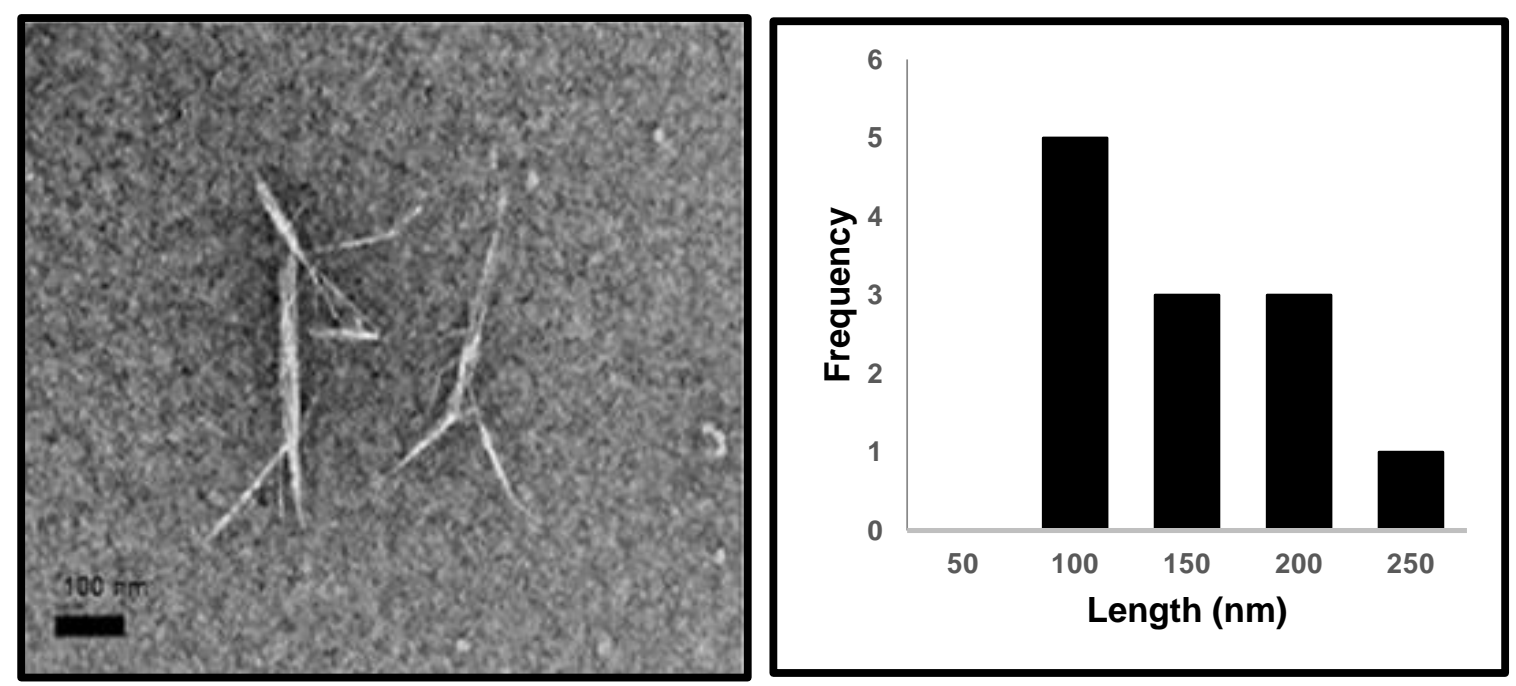

(a)

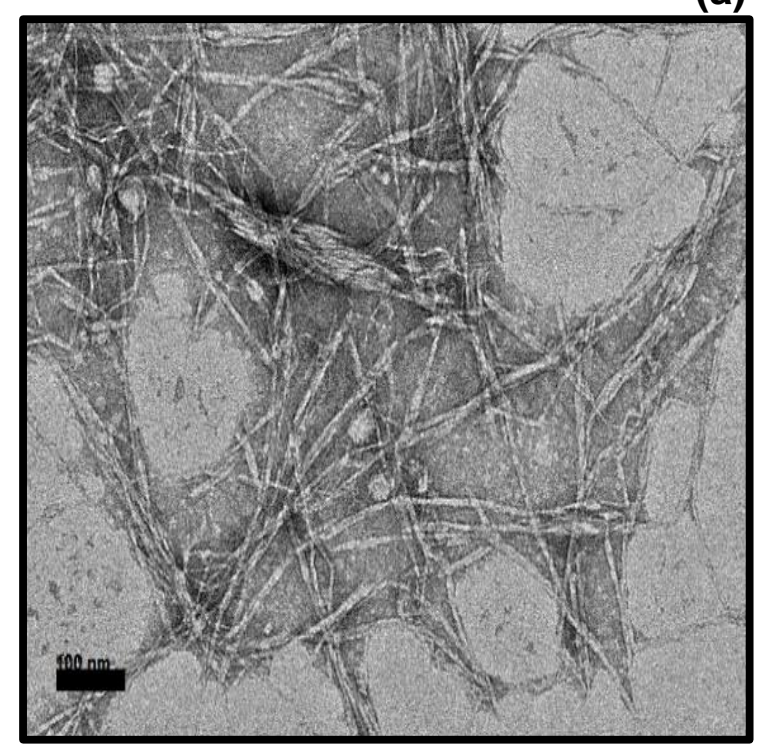

(d)

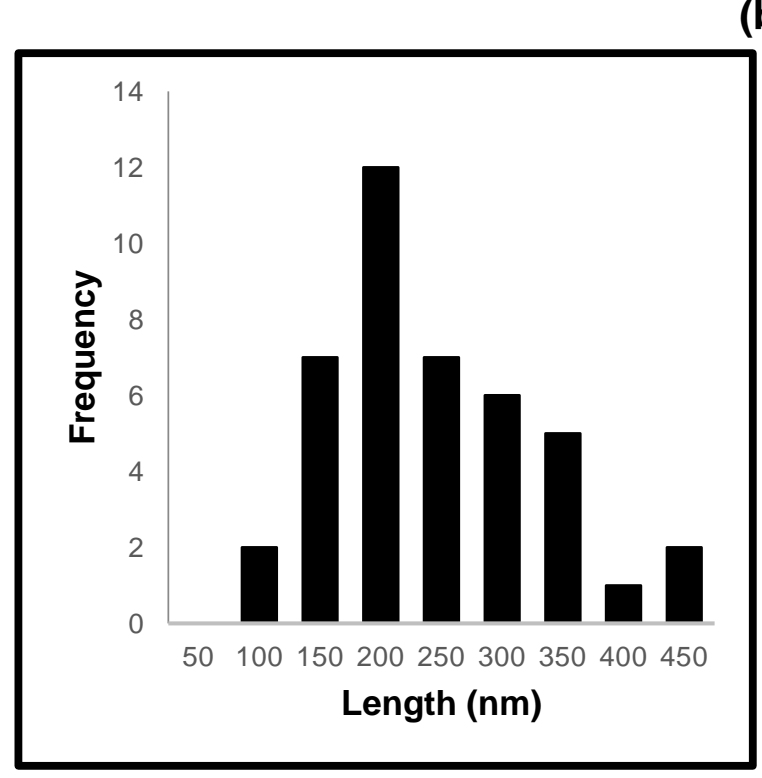

(b)

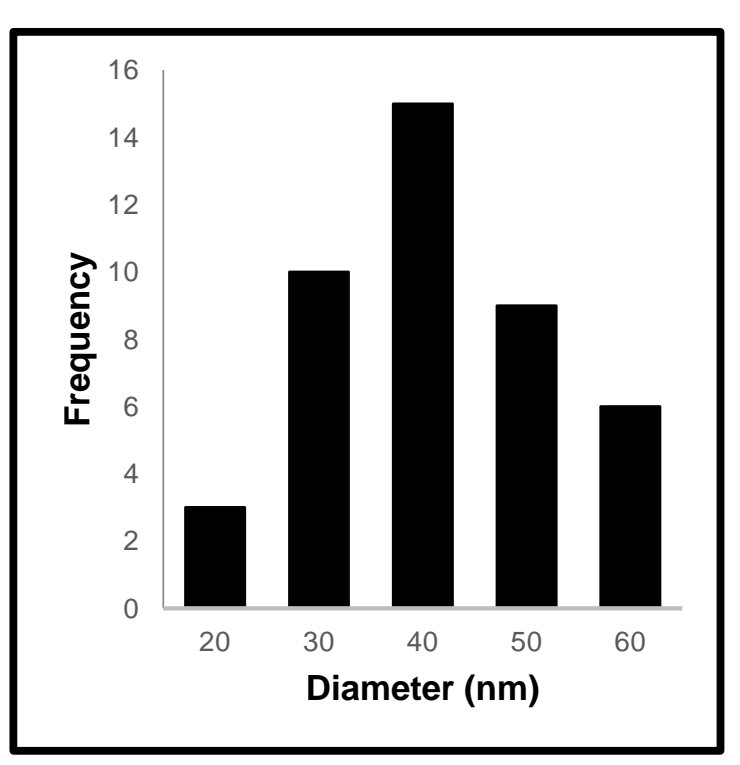

(e)

Aridi et al. (2021). "NCC from Leucaena leucocephala," BioResources 16(2), 3137-3158. 3148 


\section{bioresources.com}

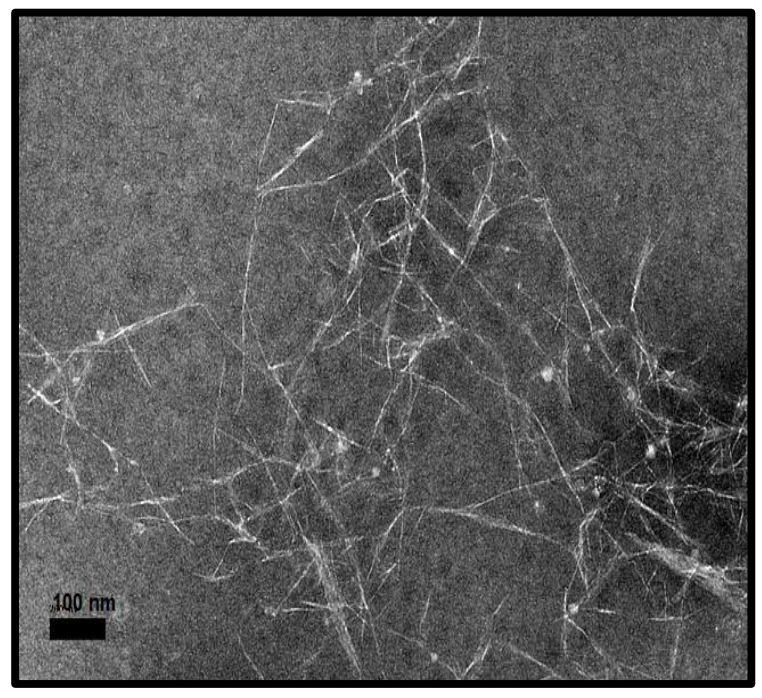

(g)

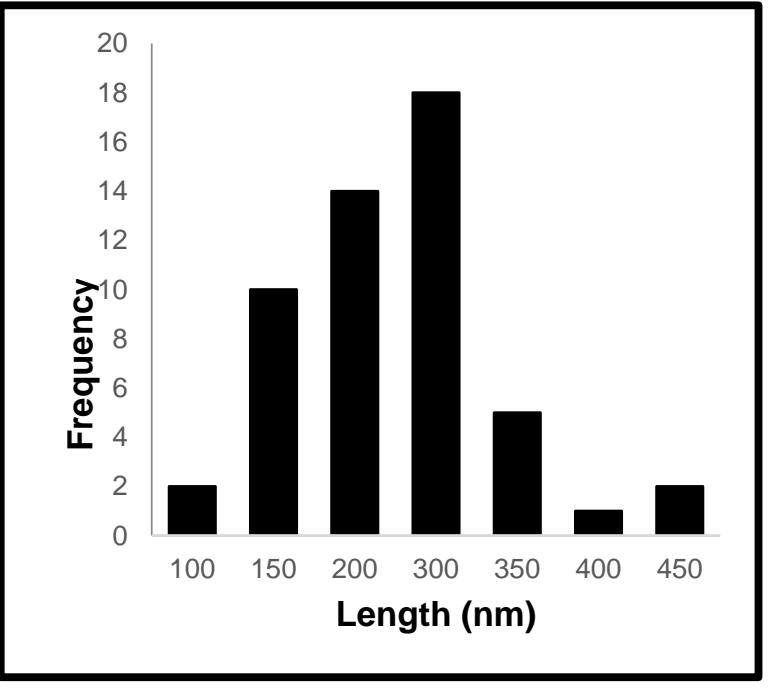

(h)

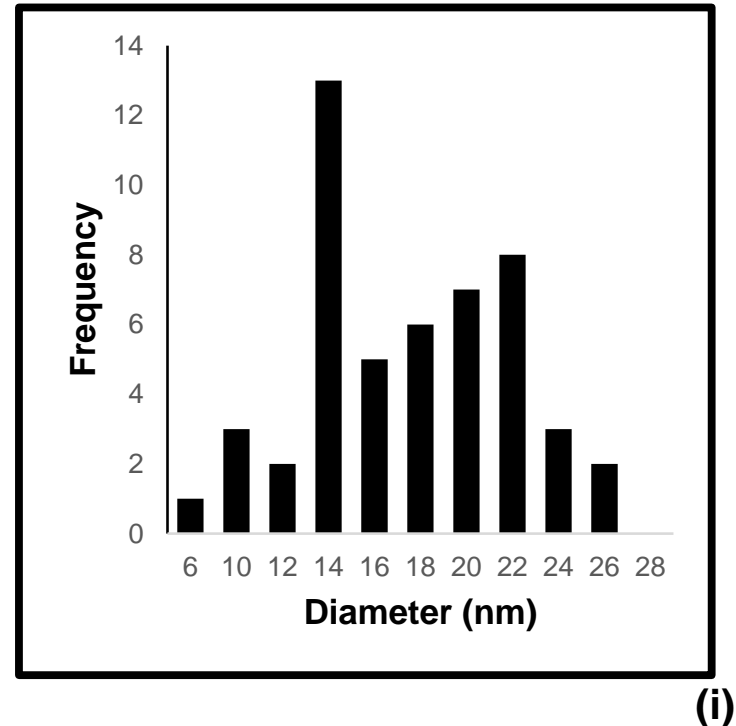

(i)

Fig. 4. TEM images of NCC treated with (a) $3 \%$, (d) $5 \%$, and (g) $7 \%$ of NaClO; length histograms of NCC treated with (b) $3 \%$, (e) $5 \%$, and (h) $7 \%$ of $\mathrm{NaClO}$; and diameter histograms of NCC treated with (c) $3 \%$, (f) $5 \%$, and (i) $7 \%$ of $\mathrm{NaClO}$ 
These images confirmed the achievement of rod-shaped nanostructure isolated from $L$. leucocephala fiber. The NCCs were characterized and analyzed by particle length $(L)$, diameter $(D)$, and aspect ratio $(L / D)$. The diameters and lengths of the NCCs after hydrolysis were determined by Image $\mathrm{J}$ (https://imagej.nih.gov/ij/), an image processing program, and are presented in Table 4. This study's NCC morphology was similar to the results obtained by Song et al. (2019). As shown in Figs. 4a, 4d, and 4g, the NCC had a needle-like cellulose nanocrystal shape. As the percentage of $\mathrm{NaClO}$ was increased, the length of the NCC produced increased (Fig. 4b, 4e, and $4 \mathrm{~h}$ ), but it decreased at $7 \%$ of $\mathrm{NaClO}$. At $3 \%$ of $\mathrm{NaClO}$, the $\mathrm{NCC}$ showed the shortest length $(133 \mathrm{~nm} \pm 66.04 \mathrm{~nm})$, while at $5 \%$ of $\mathrm{NaClO}$, the $\mathrm{NCC}$ showed the longest length $(223 \mathrm{~nm} \pm 92.83 \mathrm{~nm})$. Also, the NCC diameter was minimized $(17 \mathrm{~nm})$ when it was treated with $7 \%$ of $\mathrm{NaClO}$. The diameters of the NCCs after treatment with $3 \%$ and $5 \%$ of $\mathrm{NaClO}$ were $49 \mathrm{~nm}$ and $36 \mathrm{~nm}$, respectively. The results showed that increasing the concentration of $\mathrm{NaClO}$ improved the size of the NCC obtained. Though, the majority of the overall diameters lay in the nanometric range. The aspect ratios of the NCCs are presented in Table 4: 3.34 for NCC treated with $3 \%$ of $\mathrm{NaClO}, 6.57$ for $\mathrm{NCC}$ treated with $5 \%$ of $\mathrm{NaClO}$, and 14.54 for $\mathrm{NCC}$ treated with $7 \%$ of $\mathrm{NaClO}$.

Acid hydrolysis separates the cellulose fibers by destroying the hydrogen bonds between the cellulose polymers, thus reducing the diameters of the fibers. During sonication, the forces produced are sufficient to break some of the bonds between the glucose units, resulting in depolymerization and shorter fiber lengths in the nanometer range.

Table 4. Lengths, Diameters, and Aspect Ratios of the Obtained NCC

\begin{tabular}{|c|c|c|c|}
\hline Sample & Length $(\mathrm{nm})$ & Diameter $(\mathrm{nm})$ & Aspect Ratio \\
\hline $3 \% \mathrm{NaClO}$ & $133 \pm 66.0$ & $49 \pm 32.1$ & 3.3 \\
\hline $5 \% \mathrm{NaClO}$ & $223 \pm 92.8$ & $36 \pm 10.8$ & 6.6 \\
\hline $7 \% \mathrm{NaClO}$ & $219 \pm 86.5$ & $17 \pm 5.2$ & 14.5 \\
\hline
\end{tabular}

\section{FTIR Analysis}

The purpose of the initial FTIR analysis was to investigate alkali treatment's effect on the functional groups of the L. leucocephala fibers. The FTIR spectra of untreated fiber, alkali-treated fiber, and cellulose treated with different percentages of $\mathrm{NaClO}$ are presented in Fig. 5. The band located at approximately $1735 \mathrm{~cm}^{-1}$ in the spectrum of the untreated $L$. leucocephala fibers was attributed to $\mathrm{C}=\mathrm{O}$ stretching of the acetyl and uronic ester groups of hemicellulose or ester linkages of carboxylic groups of ferulic and p-coumaric acids of lignin and xylan in hemicellulose (Ilyas et al. 2018; Song et al. 2019). After the fiber had undergone alkali treatment with sodium hydroxide, the band at $1735 \mathrm{~cm}^{-1}$ was no longer observed in the FTIR spectra. However, the band between 1511 and $1546 \mathrm{~cm}^{-1}$, related to lignin, was still observed in the FTIR spectrum of the alkali-treated fiber. This result showed that the alkali treatment with sodium hydroxide only removed hemicellulose from the L. leucocephala fiber and did not fully remove the lignin.

Next, FTIR analysis was also used to study the effect of using different percentages of $\mathrm{NaClO}$ during the bleaching process on removing lignin from the alkali-treated $L$. leucocephala fibers in nanocrystalline cellulose (NCC) and presented in Fig. 6. Similar results were observed for water hyacinth (Eichhornia crassipes) fiber, as Asrofi et al. (2018) reported. They found that this particular band did not appear after the pre-treatment step. 


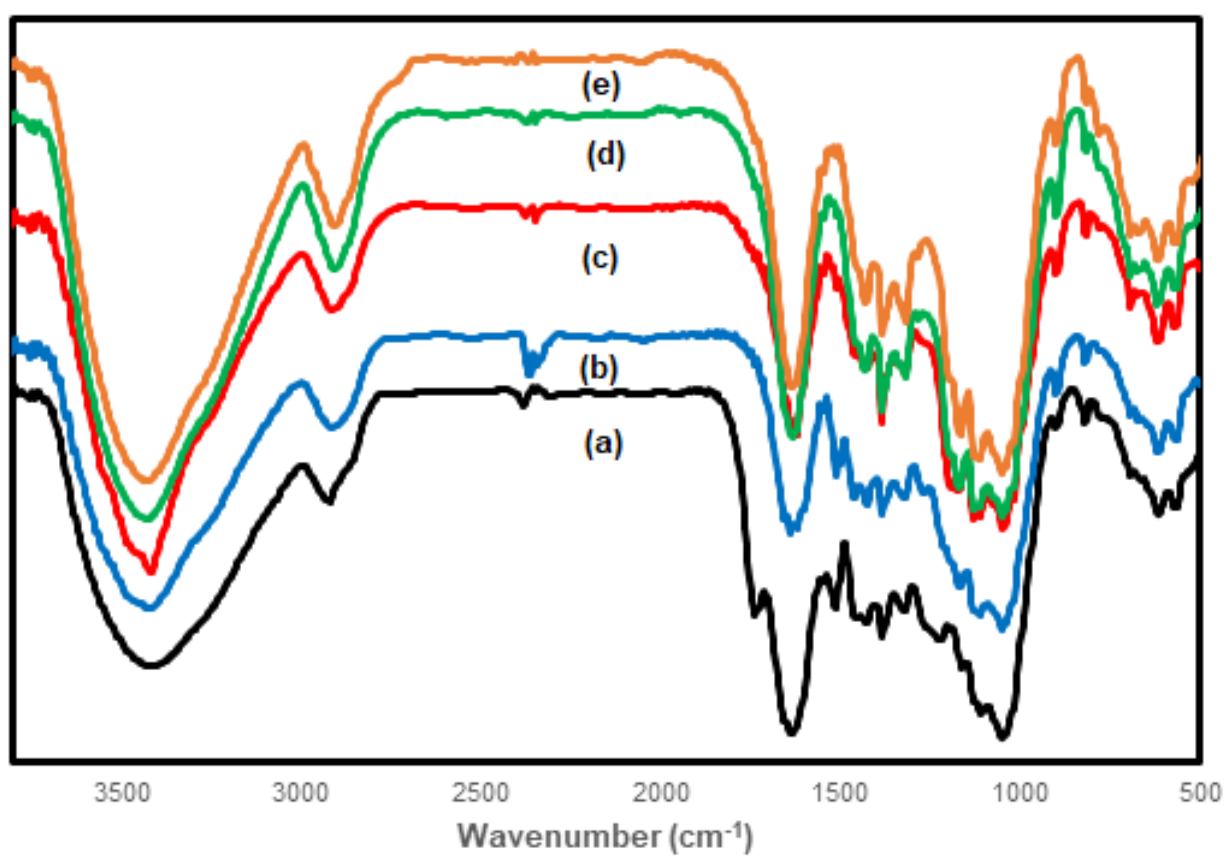

Fig. 5. FTIR spectra of (a) untreated fiber, (b) alkali-treated fiber, (c) 3\%-NaClO-treated cellulose isolated from $L$. leucocephala fiber, (d) $5 \%-\mathrm{NaClO}$-treated cellulose isolated from $L$. leucocephala fiber, and (e) 7\%-NaClO-treated cellulose isolated from L. leucocephala fiber

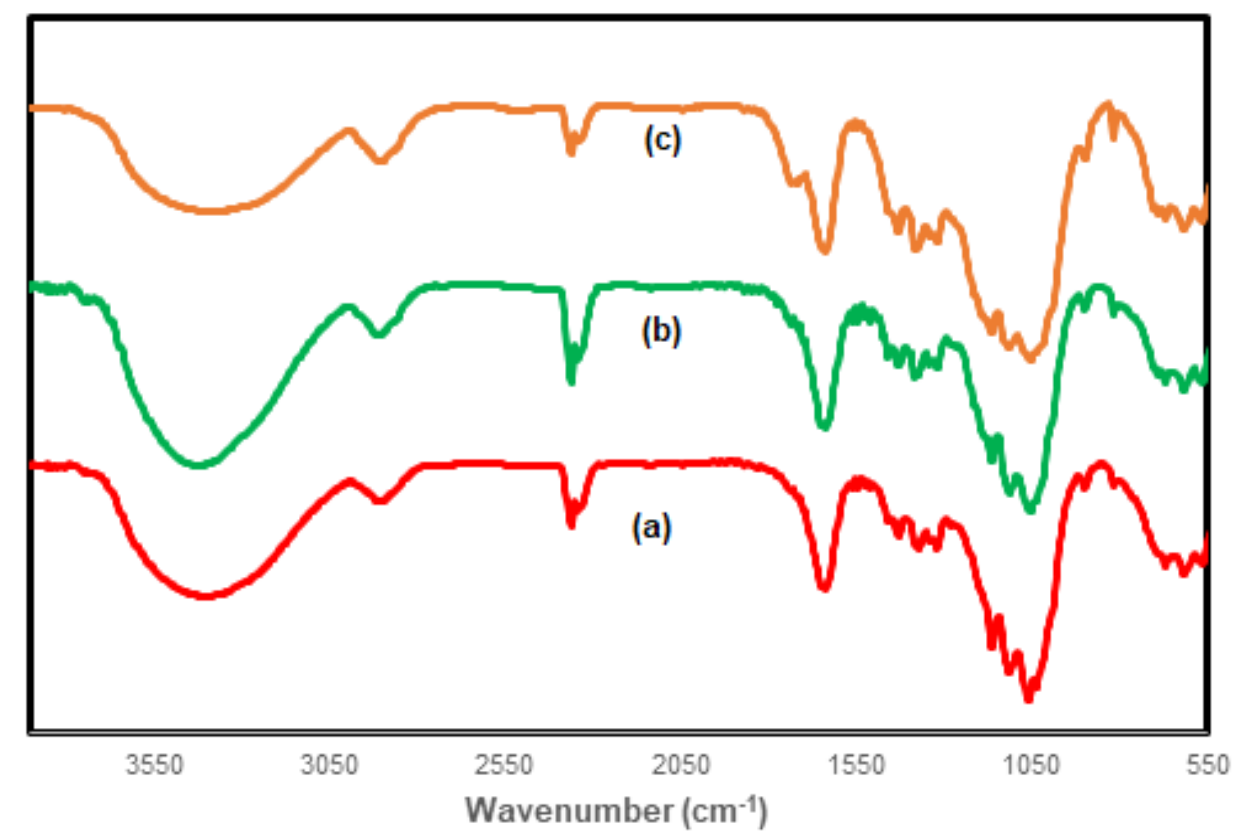

Fig. 6. FTIR spectra of NCC isolated from L. leucocephala fiber, treated with (a) NCC treated with $3 \% \mathrm{NaClO}$, (b) NCC treated with $5 \% \mathrm{NaClO}$, and (c) NCC treated with $7 \% \mathrm{NaClO}$

The band between 1511 and $1546 \mathrm{~cm}^{-1}$ was identified as the aromatic skeletal vibrations of lignin and lignocellulose's functional groups. The band at $1508 \mathrm{~cm}^{-1}$ was observed for the cellulose treated with $1 \%$ of $\mathrm{NaClO}$. However, the band disappeared when the fiber underwent the bleaching treatment with an increased percentage of $\mathrm{NaClO}$. It was 
suggested that using 3\% and greater $\mathrm{NaClO}$ effectively removed lignin from the fibers. Moreover, all samples' spectra showed the characteristic $\mathrm{C}-\mathrm{H}$ stretching vibrations at approximately $2900 \mathrm{~cm}^{-1}$ (Mandal and Chakrabarty 2011).

Similar FTIR spectra patterns were observed in previous studies (Rahman et al. 2017; Song et al. 2019). The cited authors found that, with alkali treatment with $\mathrm{NaOH}$, the peaks slowly diminished in the spectra due to the elimination of hemicellulose and lignin during the pre-treatment step. Though different bleaching agents (a mixture of sodium chlorite and acetic acid solution) were used to produce a white powder, the disappearance of these two bands was observed after the fiber's bleaching process.

\section{Crystallinity Analysis}

In nature, cellulose consists of both crystalline and amorphous regions, whereas hemicellulose and lignin are amorphous (Rahman et al. 2017). The acid hydrolysis process's aim during isolation of NCC was to eliminate the amorphous regions from the NCC. X-ray diffraction analysis was used to determine the crystallinity indices of the NCCs produced from the L. leucocephala fibers. Jasmani and Thielemans (2018) stated that crystalline cellulose exists in at least four allomorphic forms: celluloses I, II, III, and IV. Cellulose $I$ is the most common type found in nature. Cellulose $\mathrm{I}_{\beta}$ is found in larger amounts in higher plants such as wood or animals such as tunicates, while cellulose $I_{\alpha}$ is dominant in algae and bacterial cellulose. Thus, the diffractogram peak (Fig. 7) corresponded to the typical crystalline character of cellulose $\mathrm{I}_{\beta}$. According to Ilyas et al. (2018), the structure of crystalline materials can be determined using X-ray diffractograms, in which a mixture of polymorphs of cellulose I will show peaks at $2 \theta=15^{\circ}$ and $22.69^{\circ}$, and cellulose II will show peaks at $2 \theta=12.3^{\circ}$ and $22.1^{\circ}$.

The X-ray diffractograms of the L. leucocephala (Lam.) de Wit fiber at different chemical treatments steps and the NCC obtained are shown in Fig. 7. The major intensity peak was observed at a $2 \theta$ value of approximately $22.19^{\circ}$ to $22.8^{\circ}$, showing that all samples existed in cellulose I's crystalline structure. Meanwhile, the low intensity at a $2 \theta$ value of approximately $18^{\circ}$ was labeled an amorphous region. The intensities of the peaks increased as the percentage of $\mathrm{NaClO}$ used during bleaching increased. This result showed that a higher percentage of bleaching agent was efficient in removing lignin from the fiber.

The XRD analysis was used to calculate the crystallinity indices of the NCCs. The crystallinity index of NCC can be expressed as the diffraction ratio from a crystalline region to the total diffraction of the sample (Zaki et al. 2018). A crystallinity degree in fibers' structure can be identified by observing the sharpness of the diffraction peak (Ilyas et al. 2018). A sharper diffraction peak indicates a higher crystallinity degree of the fibers. The crystallinity index was determined by Eq.5, the intensity of 200 peaks $\left(I_{200}, 2 \theta=22.5^{\circ}\right)$ and the minimum between the 200 and 110 peaks $\left(I_{\mathrm{am}}, 2 \theta=18^{\circ}\right) ; I_{200}$ represents both crystalline and amorphous material, while $I_{\mathrm{am}}$ represents amorphous material.

Table 5 shows that the $7 \%-\mathrm{NaClO}$-treated $\mathrm{NCC}$ had the highest crystallinity index $(71.1 \%)$, while the untreated fiber had the lowest $(34.6 \%)$. The increase in the NCC's crystallinity index produced, as compared to the untreated L. leucocephala fiber, could be explained by the reduction and removal of amorphous non-cellulosic compounds. The increase in the NCC crystallinity after acid hydrolysis treatment was also observed in previous studies (Ilyas et al. 2018; Song et al. 2019). However, this value was lower compared to NCC from tea leaf (83.1\%) (Rahman et al. 2017), sugar palm fibers (85.9\%) (Ilyas et al. 2018), and sugarcane bagasse (72.5\%) (Kumar et al. 2014). However, the crystallinity index of the NCC produced from the L. leucocephala fiber was comparable 
with those of NCC produced from Calotropis procera (68.7\%) (Song et al. 2019) and Pandanus tectorius (69.5\%) (Sheltami et al. 2012).

The crystallinity values were varied, as they depend on the different types of plants and the time during the hydrolysis process. According to previous work, there is a relation between crystallinity and cellulose stiffness, where high crystallinity regions produce high stiffness of fibers. Hence, NCC's mechanical properties can be upgraded by controlling the conditions of the hydrolysis process.

Table 5. Crystallinity Indices (Crl) of All Samples

\begin{tabular}{|c|c|}
\hline Sample & Crl (\%) \\
\hline Untreated fiber & 34.6 \\
\hline Alkali treated fiber & 51.8 \\
\hline $3 \%$ of $\mathrm{NaClO}$ & 53.0 \\
\hline $5 \%$ of $\mathrm{NaClO}$ & 60.4 \\
\hline $7 \%$ of $\mathrm{NaClO}$ & 71.1 \\
\hline
\end{tabular}

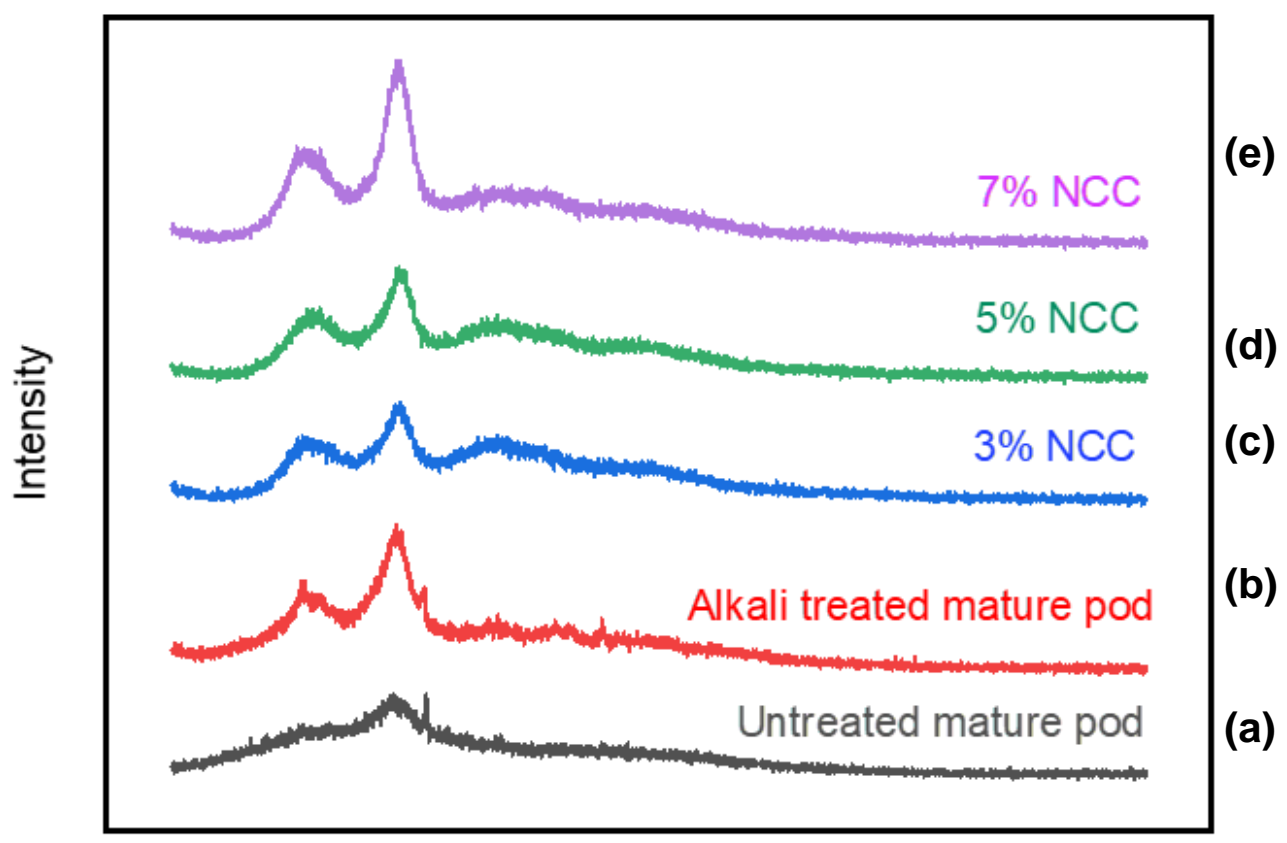

\section{Theta}

Fig. 7. (a) X-ray diffractogram of untreated fiber, (b) alkali-treated fiber, and (c) $3 \%$ NCC isolated from $L$. leucocephala fiber, (d) $5 \%$ NCC isolated from L. leucocephala fiber, (e) $7 \%$ NCC isolated from $L$. leucocephala fiber

\section{Density and Moisture Content}

One of the most important characteristics that must be considered for a new natural materials as potential additive, especially in food, is moisture content. Therefore, it is an important parameter used to determine the properties and the end uses of the obtain fiber. Most food powders have low moisture content, thus reducing the rate of quality degradation. High moisture content material could weaken the stability of the materials and also its compressibility. From Table 6 , the moisture content of commercial cellulose was 
the lowest among all the samples. 5\% NCC showed a lower moisture content compared to $3 \%$ and $7 \%$ NCC.

Next, density is an important structural property in materials. As a physical characteristic, density is necessary in engineering calculations and is a quality parameter in both mid-state (at intermediate stages of drying and food processing) and after completion of drying and food processing. The density of untreated, alkali treated and NCC obtained were ranging between 1.37 and $1.47 \mathrm{~g} / \mathrm{cm}^{3}$. The density of NCC was lower if compared to untreated and alkali-treated fibers because of the removal of main component such as lignin and hemicellulose from the fibers. Not much difference on the density values can be compare between NCC from L. leucocephala fiber with conventional manmade fiber such as aramid $\left(1.4 \mathrm{~g} / \mathrm{cm}^{3}\right)$, and carbon $\left(1.7 \mathrm{~g} / \mathrm{cm}^{3}\right)$ (Ilyas et al. 2017).

Table 6. Density and Percentage of Moisture of all Samples

\begin{tabular}{|l|c|c|l|}
\hline \multicolumn{1}{|c|}{ Sample } & Density (g/cm3) & Moisture content (wt.\%) & \multicolumn{1}{|c|}{ Reference } \\
\hline $\begin{array}{l}\text { Untreated L. leucocephala } \\
\text { mature pod }\end{array}$ & $1.45 \pm 0.01$ & $14.8 \pm 0.23$ & Current study \\
\hline Alkali-treated mature pod & $1.47 \pm 0.01$ & $13.9 \pm 0.21$ & Current study \\
\hline $3 \%$ NCC & $1.42 \pm 0.01$ & $14.0 \pm 0.01$ & Current study \\
\hline $5 \%$ NCC & $1.37 \pm 0.01$ & $6.5 \pm 2.12$ & Current study \\
\hline $7 \%$ NCC & $1.42 \pm 0.01$ & $10.5 \pm 0.63$ & Current study \\
\hline Commercial cellulose & $1.55 \pm 0.01$ & $3.9 \pm 0.12$ & Current study \\
\hline Sugar palm NCC & $1.05 \pm 0.00$ & $17.9 \pm 0.01$ & $\begin{array}{l}\text { (llyas, Sapuan, and } \\
\text { Ishak 2017) }\end{array}$ \\
\hline
\end{tabular}

\section{CONCLUSIONS}

1. Nanocrystalline cellulose (NCC) was successfully isolated from Leucaena leucocephala (Lam.) de Wit fibers after alkali treatment $(\mathrm{NaOH})$, bleaching $(3 \%, 5 \%$, and $7 \%$ of $\mathrm{NaClO})$, and acid hydrolysis $\left(\mathrm{H}_{2} \mathrm{SO}_{4}\right)$.

2. The Fourier transform infrared (FTIR) spectroscopy results showed that the alkali treatment $(\mathrm{NaOH})$ and bleaching $(3 \%, 5 \%$, and $7 \% \mathrm{NaClO})$ steps effectively removed lignin and hemicellulose. The X-ray diffraction (XRD) analysis showed that the NCC's crystallinity index increased as the percentage of $\mathrm{NaClO}$ used during bleaching was increased.

3. The transmission electron micrograph (TEM) images revealed that the NCC produced had a rod-like shape, with diameters ranging from $17 \mathrm{~nm}$ to $49 \mathrm{~nm}$.

4. L. leucocephala fibers could be used as a preliminary material for NCC preparation. Using $7 \%$ of $\mathrm{NaClO}$ during bleaching treatment resulted in the best $\mathrm{NCC}$ based on the greatest crystallinity index. The NCC's physical, chemical, and morphological properties have great potential as bioderived reinforcement in nanocomposites and for use in food packaging. 


\section{ACKNOWLEDGMENTS}

The authors are very thankful to Universiti Putra Malaysia for providing necessary facilities under Putra Grant - Putra Graduate Initiative (IPS) with the vote number of 9635400, and Universiti Kuala Lumpur MICET for providing FTIR analysis to carry out the study. Aridi, A. S., is grateful to Universiti Tun Hussein Onn Malaysia (UTHM) for the scholarship.

\section{REFERENCES CITED}

Abdul Rahman, N. H., Chieng, B. W., Ibrahim, N. A., and Abdul Rahman, N. (2017). "Extraction and characterization of cellulose nanocrystals from tea leaf waste fibers," Polymers 9, 1-11.

Aborisade, A. B., Adetutu, A. and Owoade, A. O. A., and Sain, M. (2017).

"Phytochemical and proximate analysis of some medicinal leaves phytochemical and proximate analysis of some medicinal leaves," Clinical Medicine Research 6(6), 209-214. DOI: 10.11648/j.cmr.20170606.16

Aminah, A., and Wong, C. C. (2004). "Dry matter productivity and nutritive quality of leucaena hybrid lines for high protein feed production," Journal of Tropical Agriculture and Food Science 32(2), 251-256.

Aridi, A. S., Chin, N. L., Ishak, N. A., Mohammad Yusof, N. N., Mohamed Ahmed, M. F., and Yusof, Y. A. (2020). "Structural FTIR analysis of cellulose functional groups isolated from Leucaena leucocephala pods using different bleaching agents," AgriRxiv. DOI: 10.31220/agriRxiv.2020.00026.

Asrofi, M., Abral, H., Kasim, A., Pratoto, A., Mahardika, M., Park, J.-W., and Kim, H.-J. (2018). "Isolation of nanocellulose from water hyacinth fiber ( WHF ) produced via digester-sonication and its characterization," Fibers and Polymers 19(8), 1618-1625. DOI: $10.1007 / \mathrm{s} 12221-018-7953-1$

Aurelia, C., Murdiati, A., Supriyanto, and Ningrum, A. (2019). "Effect of sodium hydroxide and sodium hypochlorite on the physicochemical characteristics of jack bean skin (Canavalia ensiformis)," Pakistan Journal of Nutrition 18(2), 193-200. DOI: 10.3923/pjn.2019.193.200

Bondeson, D., Mathew, A., and Oksman, K. (2006). "Optimization of the isolation of nanocrystals from microcrystalline cellulose by acid hydrolysis," Cellulose 13, 171180. DOI: 10.1007/s10570-006-9061-4

Browning, B. L. (1967). "Lignin," in” Methods of Word Chemistry, Vol. 2, John Wiley \& Sons, USA, pp. 785-795.

Dos Santosa, M., R., Neto, W. P. F., Hudson A. S., Martins, D. F., Dantas, N. O., and Pasquini, D. (2013). "Cellulose nanocrystals from pineapple leaf , a new approach for the reuse of this agro-waste," Industrial Crops \& Products 50, 707-714. DOI: 10.1016/j.indcrop.2013.08.049

Dufresne, A. (2013). "Nanocellulose: A new ageless bionanomaterial," Materials Today 16(6), 220-227. DOI: 10.1016/j.mattod.2013.06.004

Garside, M. (2021). Global market value of nanocellulose 2020 \& 2025.

Hakimi, M. I., Khalilullah, Goembira, F., and Ilham, Z. (2017). "Engine-compatible biodiesel from Leucaena leucocephala seed oil," Journal of the Society of Automotive Engineers Malaysia 1(2), 86-93. 
Halib, N., Perrone, F., Cemazar, M., Dapas, B., Farra, R., Abrami, M., Chiarappa, G., Forte, G., Zanconati, F., Pozzato, G., et al. (2017). "Potential applications of nanocellulose-containing materials in the biomedical field," Materials 10(8). DOI: 10.3390/ma10080977

Husin, M., and Ab, N. A. N. (2019). "Cellulose isolation from Leucaena leucocephala seed: Effect on concentration sodium hydroxide," Journal of Academia 7(2), 36-45. DOI: $10.24191 /$ jfast.v7i2.7184.

Ilyas, R. A., Sapuan, S. M., and Ishak, M. R. (2018). "Isolation and characterization of nanocrystalline cellulose from sugar palm fibres (Arenga pinnata)," Carbohydrate Polymers 181, 1038-1051. DOI: 10.1016/j.carbpol.2017.11.045.

Jahan, M. S., Saeed, A., He, Z., and Ni, Y. (2011). "Jute as raw material for the preparation of microcrystalline cellulose," Cellulose 18(2), 451-459. DOI: $10.1007 / \mathrm{s} 10570-010-9481-\mathrm{z}$

Jasmani, L., and Thielemans, W. (2018). "Preparation of nanocellulose and its potential application," Forest Research 7(3). DOI: 10.4172/2168-9776.1000222

Kamel, R., El-wakil, N. A., Dufresne, A., and Elkasabgy, N. A. (2020). "Nanocellulose: From an agricultural waste to a valuable pharmaceutical ingredient," International Journal of Biological Macromolecules 163, 1579-1590. DOI: 10.1016/j.ijbiomac.2020.07.242

Khanna, N. K., Shukla, O. P., Gogate, M. G., Narkhede, S. L., and Delhi, N. (2019). "Leucaena for paper industry in Gujarat, India: Case study. Tropical GrasslandsForrajes Tropicale," 7(November 2018), 200-209. DOI: 10.17138/TGFT(7)200-209

Kumar, A., Negi, Y. S., Choudhary, V., and Bhardwaj, N. K. (2014). "Characterization of cellulose nanocrystals produced by acid-hydrolysis from sugarcane bagasse as agrowaste," Journal of Materials Physics and Chemistry 2(1), 1-8. DOI: 10.12691/jmpc2-1-1

Lavoine, N., Desloges, I., Dufresne, A., and Bras, J. (2012). "Microfibrillated cellulose Its barrier properties and applications in cellulosic materials: A review," Carbohydrate Polymers 90(2), 735-64. DOI: 10.1016/j.carbpol.2012.05.026

Lim, T. K. (2012). Edible Medicinal and Non-medicinal Plants: Vol. 4, Fruits, Springer, Dordrecht, The Netherlands. DOI: 10.1007/978-94-007-4053-2

Mandal, A., and Chakrabarty, D. (2011). "Isolation of nanocellulose from waste sugarcane bagasse (SCB) and its characterization," Carbohydrate Polymers 86(3), 1291-1299. DOI: 10.1016/j.carbpol.2011.06.030

Masafu, M. M. (2006). The Evaluation of Leucaena leucocephala (Lam) de Wit: A Renewable Protein Supplement for Low-quality Forages, Ph.D. Dissertation, University of South Africa, Pretoria, South Africa.

Mohd, W., Wan, N., Rahman, A., Nabilah, A., and Noorbaini, S. (2020). "Leucaena leucocephala: A fast-growing tree for the malaysian particleboard industry," BioResources 15(4), 7433-7442.

Nuruddin, M., Chowdhury, A., Haque, S. A., Rahman, M., Farhad, S. F., Sarwar Jahan, M., and Quaiyyum, A. (2011). "Extraction and characterization of cellulose microfibrils from agricultural wastes in an integrated biorefinery initiative," Cellulose Chemistry Technology 45(5-6), 347-354.

Pandey, V. C., and Kumar, A. (2013). "Leucaena leucocephala: An underutilized plant for pulp and paper production," Genetic Resources and Crop Evolution 60(3), 1165 1171. DOI: 10.1007/s10722-012-9945-0

Phanthong, P., Reubroycharoen, P., Hao, X., Xu, G., Abudula, A., and Guan, G. (2018). 
"Nanocellulose: Extraction and application," Carbon Resources Conversion 1(1), 32 43. DOI: $10.1016 /$ j.crcon.2018.05.004

Rahman, H. A., Rahman, W. M. W. A., Kasim, J., Japarudin, Y., and Pailing, M. (2014). "Leucaena leucocephala a fast growing tree for Malaysian wood-based industry," in: $4^{\text {th }}$ International Plantation Industry Conference \& Exhibition (IPiCEX 2014), Kuching, Malaysia, pp. 1-13.

Rahman, N. H. A., Chieng, B. W., Ibrahim, N. A., and Rahman, N. A. (2017). "Extraction and characterization of cellulose nanocrystals from tea leaf waste fibers," Polymers 9(11). DOI: 10.3390/polym9110588

Samir, M. A. S. A., Alloin, F., and Dufresne, A. (2005). "Review of recent research into cellulosic whiskers, their properties and their application in nanocomposite field," Biomacromolecules 6(2), 612-626. DOI: 10.1021/bm0493685

Sethi, P., and Kulkarni, P. R. (1994). "Chemical composition of Leucaena leucocephala seeds," International Journal of Food Sciences and Nutrition 45(1), 5-13. DOI: 10.3109/09637489409167012

Sethi, P., and Kulkarn, P. R. (1995). "Food-science Leucaena leucocephala. A nutrition profile," Food and Nutrition Bulletin 16(3), 1-16.

Sheltami, R. M., Abdullah, I., Ahmad, I., Dufresne, A., and Kargarzadeh, H. (2012). "Extraction of cellulose nanocrystals from mengkuang leaves (Pandanus tectorius)," Carbohydrate Polymers 88(2), 772-779. DOI: 10.1016/j.carbpol.2012.01.062

Shokri, J., and Adibkia, K. (2013). "Application of cellulose and cellulose derivatives in pharmaceutical industries," in: Cellulose: Medical, Pharmaceutical and Electronic Applications, T. G. M. Van De Ven (ed.), IntechOpen, London, UK, pp. 47-66. DOI: $10.5772 / 55178$

Song, K., Zhu, X., Zhu, W., and Li, X. (2019). "Preparation and characterization of cellulose nanocrystal extracted from Calotropis procera biomass," Bioresources and Bioprocessing 6. DOI: 10.1186/s40643-019-0279-z

Statista Research Department. (2016). U.S. cellulose fiber market value by application 2014-2025.

Teixeira, E. d. M., Bondancia, T. J., Teodoro, K. B. R., Corrêa, A. C., Marconcini, J. M., and Mattoso, L. H. C. (2011). "Sugarcane bagasse whiskers: Extraction and characterizations," Industrial Crops and Products 33(1), 63-66. DOI:

10.1016/j.indcrop.2010.08.009

Ummartyotin, S., and Manuspiya, H. (2015). "A critical review on cellulose: From fundamental to an approach on sensor technology," Renewable and Sustainable Energy Reviews 41, 402-412. DOI: 10.1016/j.rser.2014.08.050

Verma, S. (2016). "A review study on Leucaena leucocephala: A multipurpose tree," International Journal of Scientific Research in Science, Engineering and Technology 2(2), 103-105.

Wertz, J.-L., Bédué, O., and Mercier, J. P. (2010). Cellulose Science and Technology. $1^{\text {st }}$ Ed. EPFL Press, Laussane, Switzerland.

Yen, M.-T., Yang, J.-H., and Mau, J.-L. (2009). "Physicochemical characterization of chitin and chitosan from crab shells," Carbohydrate Polymers 75(1), 15-21. DOI: 10.1016/j.carbpol.2008.06.006

Zaki, A. S. C., Yusoff, N. A., Rohaizad, N. M., Sohaimi, K. S. A., Mohamed, A. R., Salleh, N. H. M., and Termizi, S. N. A. A. (2018). "Isolation and characterization of nanocellulose structure from waste newspaper," Journal of Advanced Research in Engineering Knowledge 5(1), 27-34. 
Zheng, D., Zhang, Y., Guo, Y., and Yue, J. (2019). "Isolation and characterization of nanocellulose with a novel shape from walnut (Juglans regia $\mathrm{L}$.) shell agricultural waste," Polymers 11(7). DOI: 10.3390/polym11071130

Article submitted: September 29, 2020; Peer review completed: December 5, 2020;

Revised version received and accepted: February 23, 2021; Published: March 9, 2021.

DOI: $10.15376 /$ biores.16.2.3137-3158 